\section{UN ABORDAJE EPIDEMIOLÓGICO DE LA INFECCIÓN POR VIH-1/2 ENTRE TRABAJADORAS SEXUALES Y HOMBRES HOMOSEXUALES DE LAS ISLA DE MARGARITA, VENEZUELA}

\begin{abstract}
Durante los últimos 15 años la Isla de Margarita se ha convertido en un destino turístico del Caribe. De allí que el interés de este estudio se basó en establecer la prevalencia de la infección por VIH-1/2 entre trabajadoras sexuales y hombres gay; evaluar la correlación existente entre prácticas sexuales de los hombres gay y la infección por VIH-1/2; y evaluar la existencia de subgrupos entre las trabajadoras sexuales. El estudio se realizó en el principal municipio de la isla entre febrero de 1994 y febrero de 1995. Se practicaron censos de las trabajadoras sexuales de la calle o caminadoras y de los hombres gay. Se aplicaron dos cuestionarios: uno para establecer las características de las trabajadoras sexuales y otro para conocer las prácticas sexuales entre los hombres gay. Recolectamos suero de 115 trabajadoras sexuales $(z=1.96, \alpha=0.012)$ registradas en el hospital local (trabajadoras sexuales registradas), 26 caminadoras $(z=1.96, \alpha$ $=0.012)$ y 40 hombres gay $(z=1.645, \alpha=0.056)$. Los sueros fueron examinados por ELISA para VIH-1/2 (Abbott). Los sueros sostenidamente reactivos fueron examinados con Western Blot (Cambridge Biotech Comporation). Los resultados mostraron que $3.6 \%$ de las caminadoras y $25 \%$ de los hombres gay eran VIH-1 positivos. En el grupo de las trabajadoras sexuales registradas ningún suero se confirmó por Western Blot ni Liatek. Las trabajadoras sexuales registradas y las caminadoras mostraron ser diferentes de acuerdo a: la prueba "t" de Student para edad ( $\mathrm{p}=0.028017, \alpha=0.05)$, la prueba de WilcoxonMann-Whitney para precio/coito $(\mathrm{p}=0.000000$, $\alpha=0.05)$ y para uso del condón ( $\mathrm{p}=0.00008, \alpha$ $=0.05$ ). También observamos entre los hombres gay una importante correlación entre relaciones bisexuales y resultado positivo para el VIH-1 al emplear la prueba de Yates $x^{2}(p=0.0216372$, $\alpha=0.05)$. Creemos que las diferencias estadísticamente significativas vistas entre los dos
\end{abstract}

Recebido para publicação em 03/01/97.

\section{AN EPIDEMIOLOGICAL APPROACH TO HIV-1/2 INFECTION AMONG FEMALE SEX WORKERS AND GAY MEN OF MARGARITA ISLAND, VENEZUELA}

During the last 15 years Margarita Island has turned into a new touristic destination in the Carribean. Therefore this survey was elaborate having in view to establish the prevalence of HIV-1/2 infection among female sex workers and gay men; to evaluate correlations between sexual practices among gay men and HIV-1/2 infection; and to evaluate the existence of female sex workers subgroups. The study was done in the main touristic county of the island from February of 1994 to February of 1995. Censorships of female street sex workers and gay men were requiered. Two questionnaires were applied: on to evaluate characteristics of female sex workers and other to evaluate sexual practices among gay men. We collected sera of 115 female sex workers ( $z=1.96, \alpha=0.012)$ who were registered in the local hospital (registered sex workers), 26 female street sex workers $(z=1.96$, $\alpha=0.012)$ and 40 gay men $(z=1.645, \alpha=0.056)$. Sera samples were screened for HIV-1/2 by ELISA (Abbott). Repeatedly reactive sera were tested by Western Blot (Cambridge Biotech Corporation). Results showed that $3.6 \%$ of street sex workers and $25 \%$ of gay men were HIV-1 positive. Whereas with the registered sex workers no serum was confirmed by Western Blot Liatek. Registered sex workers and street sex workers were different according to: " $\mathrm{t}$ " Student test for age ( $\mathrm{p}=0.028017, \alpha=0.05)$ WilcoxonMann-Whitney test for sexual intercourse/price ( $p=0.000000, \alpha=0.05)$ and for condom/use $(\mathrm{p}=0.00008, \alpha=0.05)$. We also found in the gay sample a correlation between bisexual intercourses and HIV-1 positive result using Yates $\mathrm{x}^{2}$ ( $p=0.0216372, \alpha=0.05$ ). Significant statistical differences observed between street sex workers and registered sex workers could mean that they have also a different chance for HIV infection due to differences in their job's performance and their clients' sexual habits. The strong correlation observed between bisexual intercourses and HIV-1 positive result among gay men could have been due to a higher amount of sexual partners between men with bisexual practices. The results of our study suggest that AIDS spreading in both clusters is mainlly maintained by people 

sexuales y hombres homosexuales de la Isla de Margarita, Venezuela. Revista da Sociedade Brasileira de Medicina Tropical 30:255-256, mai-jun, 1997.

grupos de trabajadoras sexuales pudieran relacionarse también con un chance diferente para la infección por VIH como consecuencia de diferentes prácticas y hábitos sexuales de sus clientes. La importante correlación observada entre relaciones bisexuales y resultados positivo para VIH-1 dentro de los hombres gay pudo estar relacionado con el mayor número de parejas sexuales entre los hombres con prácticas bisexuales. Los resultados de nuestro estudio sugieren que la diseminación del SIDA entre ambos colectivos estaba mantenido a expensas de gente originaria de la Isla de Margarita, y en segundo término por venezolanos de estados vecinos. Encontramos un bajo nivel de información sobre el VIH/SIDA entre las caminadoras. El mismo pudiera estar explicado por el alto analfabetismo (23\%) de este grupo. Sin embargo, a pesar del mejor nivel de información sobre VIH/SIDA que medimos entre los gay, nuestro estudio evidenció que esta condición no fue suficiente para convencerlos en el uso del condón. Una vez mas parece claro cómo diferencias sociales y económicas entre grupos de una comunidad, mejor expresado como "la representación del VIH/SIDA", está intimamente ligada a la escena de su transmisión. Si hurgamos en estas aparentes diferencias culturales y de comportamientos, quizás encontremos importantes señas para ensamblar estrategias de control. Sugerimos para el programa de control del VIH/SIDA en Margarita mayor atención a las caminadoras y al sexo sin protección. Ello con el fin de reducir en el futuro los casos de infección por VIH en mujeres y niños. Una de estas estrategias bien puede ser el desarrollo de un voluntariado interesado en prevenir el VIH/SIDA por medio de la educación. originally from Margarita Island, and on second term from the neighboring regions of Venezuela. We found a low grade of information about HIVAIDS among the street sex workers. This is possibly due to a high illeteracy (23\%). Despite the better information level among gay men on HIV/AIDS, our study shoes there is still not sufficient use of condoms. Once more it seems clear how social and economical differences among community groups better understood as "the AIDS representation" is deeply attached to the onset of its transmission. If we look further into these apparent cultural and behavioural differences, perhaps we will find important indicators for control strategies. We suggest for Margarita's AIDS control program better attention to street sex workers and non-safe sex among men, in order to reduce future changes of HIV infection to women and children of this area. One of these strategies could well be involvement of voluntares concerned in preventing AIDS with help of educational methods.

\section{Erika Castro de Batänjer}

Tese apresentada ao Departamento de Medicina Tropical do Instituto Oswaldo Cruz para o Título de Mestre. Rio de Janeiro, RJ, Brasil, 1995. 